University of Nebraska - Lincoln

DigitalCommons@University of Nebraska - Lincoln

$12-2003$

\title{
Acceptance of the Clark P. Read Mentor Award: The Teague Self Lessons
}

John J. Janovy Jr.

University of Nebraska - Lincoln, jjanovy1@unl.edu

Follow this and additional works at: https://digitalcommons.unl.edu/bioscijanovy

Part of the Parasitology Commons

Janovy, John J. Jr., "Acceptance of the Clark P. Read Mentor Award: The Teague Self Lessons" (2003).

John Janovy Publications. 62.

https://digitalcommons.unl.edu/bioscijanovy/62

This Article is brought to you for free and open access by the Papers in the Biological Sciences at DigitalCommons@University of Nebraska - Lincoln. It has been accepted for inclusion in John Janovy Publications by an authorized administrator of DigitalCommons@University of Nebraska - Lincoln. 


\title{
ACCEPTANCE OF THE CLARK P. READ MENTOR AWARD: THE TEAGUE SELF LESSONS
}

\author{
John Janovy, Jr. \\ School of Biological Sciences, University of Nebraska-Lincoln, Lincoln, Nebraska 68588-0118
}

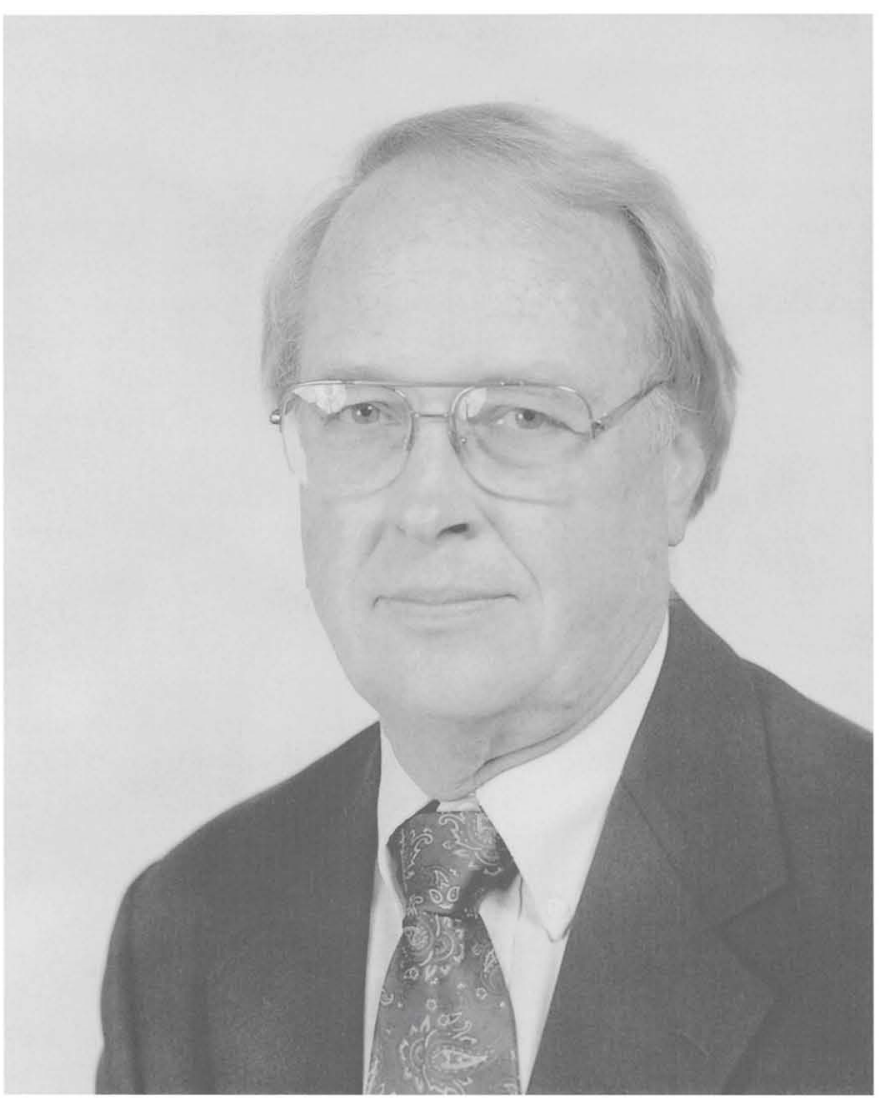

Thank you very much, Dr. Ruhnke, for that flattering introduction. My most sincere thanks to all of you too, not only for the enormous honor of standing here today but also for the equally enormous opportunity you have provided by your contributions to the American Society of Parasitologists. By keeping this society alive and well you have provided an incredibly supportive environment for the professional development of my students, and for that I am greatly indebted.

I remember Tim Ruhnke's first scientific meeting very well. As an undergraduate he'd come with us to the Southwestern Association of Parasitologists meeting at Lake Texoma. He sat there fairly patiently - actually he was squirming rather impatiently-listening to the student presentations, and after the session was over, he said, "I can do that." In retrospect, the squirming was probably his desire to get started immediately, having figured out he could "do that." And sure enough he, and a whole lot of others who came into our lab, maybe not just like him but similar in 1 way, could "do that."

The way in which they were similar was that they all were willing to invest their time and talents in an activity that had the primary goal of satisfying their own personal curiosity about the natural world. The "that" of the "do that," of course, was to pursue some problem in parasitology from idea to closure or at least to the relative closure that we consider to have been reached with presentation or publication. In making such decisions - to invest their human resources and pursue some seemingly minor question potentially of conceptual importance-all these students have provided 1 college professor with the most incredible privilege, namely that of seeing a young person make a lifetime commitment to parasitology and ultimately become a professional parasitologist.

In my admittedly biased view, there simply is no other reward in our business that matches this experience of watching a student decide to pursue a biological problem, often involving recalcitrant animals, then apply all those human resources of creativity, insight, discipline, patience with dumb animals and seemingly dumb major advisors, all in order to answer some question. But in reviewing all my past students' work in preparation for this occasion, it seems that instead of solving problems and answering questions, they all ended building their own unique pictures of the natural world. Even though hypotheses were tested and experiments were performed, in retrospect, their projects seem more like monumental sculptures than scientific works. And we all know that works of art survive the millennia, whereas scientific papers are there to be eclipsed.

What was it that these young artists parading as scientists actually accomplished? In essence, they used some project as a device for teaching themselves how to be a certain kind of biologist. What a privilege it is to have ended up in a position to watch this activity. Indeed, there are times when I simply feel sorry for those high-powered athletes with 6-, 7-, or 8figure salaries, signing bonuses and endorsement deals, those chief executive officers of multinational conglomerates, those leaders - elected or not - of great nations, those beautiful people who walk the red carpet on Academy Awards night. I tend to think of them as deprived children. None of them has had the experience of watching a student from his or her freshman zoology class become, over the course of a few years, a published scholar with a job, health insurance, and expertise (sort of in that order of priority!). None of them has ever known the cold chills, the "what have we done?" and "what do we do now?" feelings, that come from watching the chancellor of your university put a doctoral hood on 1 of your own Ph.D. students. None of those people on the cover of People Magazine has ever had the truly sensual experience of opening up that newly bound, autographed, and hand-delivered master's thesis, burying their nose in the pages, and smelling that paper, glue, and binding smell that means a young person has just brought something to closure. None of those great National Football League running backs has ever sat in an audience at a regional scientific meeting, trying to keep a solemn straight face as an undergrad from his lab shivers away in front of an audience of friends while delivering his or her first ever paper. And, I might add, 
being in a meeting where 1 of your own students, a person you remember from a freshman class but who is now a faculty member, watches his or her student deliver a paper, must indeed be the rarest of wonderful experiences!

How does one partake of this unique privilege of being a teacher in the most general sense of the word? I don't know how others do it, but in my own case, perhaps the best answer is a quote from my own major adviser, Dr. J. T. Self (JTS) at the University of Oklahoma. I don't remember the setting, but I distinctly remember him saying: "John, they always accused me of taking the best graduate students, but all I did was go in the lab and work, and those students came walking in, asking if there was something they could do."

Sure enough, when I went to Nebraska, that's what I didsimply went into the lab and started to work, and students came walking in. I believe at that time the first of those Teague Self lessons paid off and that was simply to let those students come in, not run them off because he was too busy, and treat them as if they had serious business, talk to them about parasitology as if they were colleagues instead of kids maybe half scared to death over where their curiosity had taken them. Nowadays, I watch how some of the younger faculty members in our department interact with the talent that walks in their doors, and I realize that this simple JTS lesson has not been taught everywhere. Nearly 4,000 smart and eager 18- and 19-yr-olds a year arrive at my institution alone, representing a truly staggering supply of human resources that could be directed at solving some of humanity's most perplexing problems. Observing how my fellow faculty members deal with them, I realize that as an institution we have not learned this simple JTS lesson very well. Rarely a week goes by that I don't visit with some talented, articulate senior who finally needs a letter of recommendation but who has never really talked to a faculty member, never done undergraduate research, never considered anything other than the career his or her high-school counselor, parents, or minister said to pursue. But simply by doing what Teague Self did to me, namely let me come in and talk, a surprising number of those 4,000 students a year have stuck around in the lab, found something to do, and eventually published enough to get me a merit raise most years, deserved or not.

I believe that the most valuable of Dr. Self's lessons, however, was his willingness to give away problems. Our projects were always our own, used as vehicles for our own intellectual development, and never part of his grand scheme, used as a means to promote his reputation. I may be deluding myself to think that I gave away any good thesis problems to students. In retrospect, I think maybe they simply took those problems away from some conversation we had and turned them into their own identity. No matter what the project, from physiology of trypanosomatids or control of life-cycle events to host specificity in gregarines or lung flukes, i.e., from 1966 to 2003, it usually took only a few weeks before our roles were reversed, before these students became the local experts and I became the very interested bystander, glassware washer, writer of memos to various committees, and form-signer. Although Dr. Self never said this to me directly, I know that I came away from the University of Oklahoma totally convinced that it was not only okay but also expected for this role reversal to happen. Indeed, if it didn't happen, then the teacher had failed.

After taking a job at the University of Nebraska, Karen and
I made regular holiday trips to Oklahoma. Often, we also went to visit Teague Self. On 1 occasion there was classical music playing on his stereo. When I asked what it was, he said "Vivaldi" as if I should have known. There was a George Sutton watercolor on his living room wall. His golf clubs were always handy. He loved entertaining, talking about art, literature, politics - academic and otherwise-and about his fellow faculty members. In other words, he taught by example that a university faculty member shouldn't be 1-dimensional. So I try to talk with my students about art, literature, politics-academic and otherwise - and my fellow faculty members. There is a famous quote, attributed about equally often to Hyman Rickover and Eleanor Roosevelt, to the effect that "Great minds discuss ideas, mediocre minds discuss things and events, and small minds talk about people." Scientists are generally stuck in the middle, spending most of their energies investigating things and events, but small-minded or not, it's the people talk that is ultimately so highly educational. And Dr. Self's people talk was extraordinarily so.

Time and time again over the past $36 \mathrm{yr}$, I have encountered situations in academia that would have been surprises had not Teague Self discussed them with us years earlier. At the time we thought it was fun - even gossipy — but he was actually telling us that biology is done by people; universities are run by people; people, not institutions, make decisions; that classes are taught by people, not by information technology; and that people vary significantly in the way they do our business. I now routinely talk with my students about professional issues in the workplace. They now routinely raise these issues in our Friday afternoon coffee house discussions. I know that they think it's fun-even gossipy - as I did at the time Teague Self had these talks with us, but from the looks on their faces and subsequent conversations, I also know they understand these talking sessions are serious. And if I've done my teaching well, then years from now these students will handle various interpersonal and workplace situations easily instead of letting them derail their careers.

I'm sure that anyone who receives this award would also like to review what he or she has learned from each of those dozens of students who have come through the lab, from undergraduates who last only a week to graduate students who receive a Ph.D. I know that in my own case this parade of talent has been exceedingly varied. It's come in a wide variety of genders, colors, sizes, shapes, nationalities, religious beliefs (or lack thereof), political stances, personalities, and personal tastes and has brought with it an equally diverse array of aspirations, at least some of which have been fulfilled. I don't always know why they came, unless they had some inner compulsion to sit at a microscope for hours, days, and weeks on end, and my lab looked like a good place to do that. There have always been lots of microscopes sitting around asking to be used. Whatever the reason, we shared some time together, and the result has been an incredibly, almost indescribably, rich and rewarding intellectual life provided to 1 teacher by his students.

I know that in the American Society of Parasitologists, indeed in this very room right now, there are students who were once in my freshman classes and who are now either faculty members or doctoral candidates. These students include 1 who wrote essays about a museum specimen - a fossil sponge - that were so compelling I used those essays, with proper acknowl- 
edgment, as book material. In this audience is a former student, now faculty member, who told me his problem was too easy; obviously, I found him a more difficult one, which he eventually published on as an undergraduate. I recall clearly the day 1 of my introductory zoology students told me that my lab teaching material was worthless, then volunteered to make an insect collection for use in our classes. He did just that, and we've used it for years; he's now a faculty member. I have sat in the music building listening to 1 of my students play an incredibly difficult recital-Prokofiev's Second Sonata in D minor-and listened to that same student give a paper at these meetings. I have watched as 1 of my graduate students mentored an undergraduate through a project to publication. I've spent 3 wk poring over complex molecular phylogenies in published papers written by a kid who made an F in a first zoology course. I've gone with parents, now also faculty members, with their children to the western Nebraska collection sites, where as graduate students they did their research so their children could wade in those same streams. This list of experiences could go on and on. I honestly believe they are common to all teachers who simply do like J. Teague Self did, namely, go in the lab and work, give away problems, and talk to their students like colleagues and friends.

Before finishing, I need to publicly thank the University of Nebraska for nearly 4 decades of support but more than that to publicly thank the citizens of Nebraska for sending thousands of their sons and daughters to our university. At times I'm truly amazed at the leap of faith involved in this decision to send your kid, or go, to college. Yet, without that leap of faith, we'd be out of business. I also need to make special mention of my colleague at the University of Nebraska, Dr. Brent B. Nickol, a previous winner of this same award. Shortly after we both arrived at UNL in the fall of 1966, it became blatantly obvious that unbeknownst to itself, the institution had acquired a critical mass of parasitologists. Harold Manter had retired but was still active, Mary Lou Pritchard was active and very much a part of the program, and Dr. Manter's last graduate students, Paul Lewis and Glen Dappen, were still around. Furthermore, there were a couple of new graduate students, Moslih Ibrahim Moslih and Ellis Greiner, who had shown up on our doorstep ready to become parasitologists. One of the first things Brent said to me was "let's go collect some birds." So we did. Since that time, Brent has contributed immeasurably to my professional development. He was the first director of the Cedar Point Biological Station, where so many of my students have taken classes and done their research. I'm not sure that program would ever have gotten off the ground had it not been for Brent's, and his family's, sacrifices. But for the last $36 \mathrm{yr}$ he's also been the most evenhanded, honest, unassuming, straightforward, and supportive professional colleague a person could have. If there are department chairs listening today, my advice is to not only hire parasitologists but to hire them in pairs. One can be a loose cannon, but the other needs to be a Brent Nickol clone.

I also need to personally thank those many western Nebraska ranchers who have simply opened up their property and allowed my students and me to use it as a laboratory and classroom. These include Duane and Lois Dunwoody; the McGinley, Haythorn, Peterson, and Sillasen families; and Charles Thalken. Simply by giving us a key to the gate, they've provided a sort of metaphorical Garden of Eden, although in this case the Tree of Knowledge is probably a scraggly cottonwood with Plasmodium-infected orioles nesting in its branches, mosquito larvae in its water-filled cavities, and gregarine-infected centipedes in the leaf litter at its base. And the snakes around that western Nebraska Tree of Knowledge are doing what snakes everywhere do in the presence of parasitologists, namely, getting out of town as fast as possible.

Finally, I'd like to end with another J. T. Self quote. Again, I don't remember the context, but I certainly remember the words.

"John," he said, "you and I married up."

I believe that he was telling me 2 things. First, he was telling me that Karen had more class, dignity, and patience than I did at the time, so I should take some lessons. If he were still alive, he'd probably say the same thing today. But, second, he was also telling me about the larger role that family plays in the development of a professional scientist, especially one whose future can best be described by a cartoon sent to me 1 time by my sister-in-law. The setting in this cartoon is a cocktail party, and an attractive lady holding a glass is asking a rather plain gentleman: Tell me, just what is an ornithologist in terms of dollars and cents? She could have substituted "parasitologist" for "ornithologist," for at the time I was working on bird malaria. My own family, from my parents, John and Bernice, now deceased; my step-parents, Rachel and Sam Bristow; Karen's parents, Glenn and Genevieve Oneth, also both deceased; all the relatives on both sides; and our children, Cynthia, Jenifer, and John III, have always seemed proud to have a parasitologist in the family, even to the point sometimes of bragging or-as with our children-using their accidentally acquired knowledge as a gross-out weapon. Furthermore, they've all routinely violated that first rule of polite dining, which is to never invite a parasitologist to dinner. So, on behalf of all those students and colleagues who have been in our home over the years, I say thanks to Karen for the education in fine art, for letting us gather around the fireplace in the basement or scatter ourselves around the patio and talk big talk until the wee hours, thanks for the lemon bars, and thanks for cleaning up the mess the next morning.

Again, thank all of you for this honor this afternoon! 